\title{
Engaging with feminist postcolonial concerns through participatory action research and intersectionality
}

\author{
C. Schurr ${ }^{1}$ and D. Segebart ${ }^{2}$ \\ ${ }^{1}$ Department of Geography, Interdisciplinary Centre for Gender Studies (IZFG), University of Berne, \\ Hallerstr. 12, 3012 Bern, Switzerland \\ ${ }^{2}$ Department of Geography, Freie Universität Berlin, Malteserstr. 74-100, 12249 Berlin, Germany
}

Correspondence to: C. Schurr (schurr@giub.unibe.ch) and D. Segebart (doerte.segebart@ fu-berlin.de)

\begin{abstract}
This paper deals with the challenges of doing fieldwork as a Western researcher in the "Global South" after the (feminist) postcolonial turn. Debates within developmental geography have addressed the politics of fieldwork, questions of positionality and collaborative, participatory ways to produce knowledge. We intend to enter this discussion to find constructive ways of conducting feminist postcolonial research. Drawing on our own experiences as German researchers and development practitioners in Latin America, we discuss the potential and limits of two central feminist postcolonial approaches in development research and practice: participatory (action) research and intersectionality. Our reflections aim to show how development research and practice may benefit from integrating feminist postcolonial approaches.
\end{abstract}

"Looking back at the first encounters with the local politicians I wanted to make part of my research project, I have to acknowledge that my attempts to act in a decolonising way totally failed as the following scene "testifies": in Orellana, the female mayor was fascinated from the beginning by my project to analyse how the gender quota law has transformed local politics. She wanted me to get to know the rest of the employees in the town hall as soon as possible and thus, already on my first day, invited me to join an internal meeting. She welcomed me and introduced my research, closing with the words "so, we were chosen to be something like her "conejos de indio"" (indigenous guinea pigs). I was too slow at responding to this "joke" and I was left with the feeling that any attempt to overcome (post)colonial power relations would be quite a difficult task" (field notes Schurr, February 2009).

\section{Facing feminist postcolonial critique in the "field" of development geography}

The introductory narrative highlights the dilemma Western researchers face when doing research in the "Global South". Since feminist postcolonial scholars criticise the colonising and paternalising effects of research, Western researchers have constantly been challenged to negotiate and reflect on the power relations that constitute the "field". The beginning of feminist postcolonial criticism dates back to the 1980s, when Chandra Mohanty's "Under Western Eyes" (1986) and Gayatri Spivak's essay "Can the Subaltern Speak?" (1988) questioned the authority of Western researchers and their research practices. Mohanty, Spivak and other feminist postcolonial scholars have highlighted the situatedness (social and cultural embedding) of knowledge production and critiqued the use of universalising categories like "women" or "people of colour". Feminist postcolonialism engaged in a two-fold project: "to racialise mainstream feminist theory and to insert feminist concerns into conceptualisations of colonialism and postcolonialism" (Lewis and Mills, 2003:3).

In the meantime, development geography has increasingly incorporated postcolonial thinking (Power et al., 2006; Radcliffe, 2005; Raghuram and Madge, 2006; Sidaway, 2007; Wainright, 2008). Feminist postcolonial concerns, however, 
are still relegated to the fringe of the discipline and are mainly addressed by feminist geographers (Laurie and Calla, 2004; Radcliffe, 2006; Sharp, 2007, 2009). Power asymmetries in knowledge production, especially between Western female researchers and the non-Western women they research, have formed a central part of feminist postcolonial criticism. In this light, to do research on development issues in the "Global South" as critical feminist researchers often seems an impossible endeavour. In this paper, we would like to reflect on the question that constantly accompanied our research processes in Latin America: what should a feminist post postcolonial research agenda look like that facilitates and does not paralyse our research process?

Although (feminist) postcolonial debates around the politics of fieldwork have been ongoing now for more than two decades (for details, see the Introduction to this special issue), many of the questions remain urgent when doing fieldwork in the "Global South": how can we engage with the shifting power relations between different actors throughout a collaborative research process? How can we overcome the burden of postcolonial concerns, which can also block critically engaged scholars, without acting naïvely and still remaining sensitive to new and persisting power relations? In brief: how is it possible to engage with development geography, taking into consideration (feminist) postcolonial concerns?

This paper engages with this question to find constructive ways of conducting feminist postcolonial research. Drawing on our own experiences as German researchers and development practitioners in Latin America, we discuss in this paper the potentials and limits of two central feminist postcolonial approaches in development research and practice: participatory (action) research and intersectionality. Our reflections aim to show how development research and practice can benefit from integrating feminist postcolonial approaches by critically reflecting on participatory methods and by interrogating the intersectional dimension of (power) relations and identities that constitute the field of research and/or development practice.

\section{Towards a feminist post postcolonial research agenda}

What we identify here as a feminist post postcolonial research agenda starts with questioning simplistic dichotomies such as "First"/“Third World" or "we"/"they" and the call for a more differentiated analysis of power relations. These kinds of essentialising binaries on which early postcolonial thinking was built have been increasingly criticised. Mohanty $(2003 \mathrm{a}, \mathrm{b})$ acknowledges the need for a more differentiated analysis of power relations in (de)colonisation processes when revisiting her famous paper "Under Western Eyes" (1986). In her view, ongoing globalisation processes make it necessary to move away from "geographical and ide- ological binarisms" (Mohanty, 2003b:506). She argues that "[w]hile my earlier focus was on the distinction between "Western" and "Third World" feminist practices, and while I downplayed the commonalities between these two positions, my focus now is on what I have chosen to call an anticapitalist transnational feminist practice - and on the possibilities, indeed on the necessities, of cross-national feminist solidarity" (2003b:509). Such "cross-national feminist solidarity" can be built on ideas of "dialogical standpoint theory" as developed by Patricia Hill Collins (1990), who argues that the one marginal, critical standpoint does not exist and thus advocates a critical dialogue between positions. This kind of dialogue may lead to the identification of similarities in perspectives that result in politics of solidarity between standpoints and hence to a de-centring of dominant discourses and knowledge claims. Sara Koopman (2011) formulates a position similar to Mohanty's when she calls for making connections across distance and difference to challenge hegemonic discourses and practices of geopolitics. As she puts it, "feminist geopolitics is not just about critiquing hegemony, but also about pointing to, and (...) creating alternatives" (Koopman, 2011:277). Koopman's call to produce alternative geopolitics in processes of collaborative thinking is in a way refreshing, since it overcomes postcolonial paralysis and is instead nourished by earlier feminist understandings of research as a transformative practice. While her call for transformative and collaborative feminist research practices is compelling, the question remains as to how collaborative research processes can deal with unequal power relations resulting from (post)colonial geopolitics (of knowledge).

\section{Participatory approaches between tyranny and transformation}

In this section, we reflect on the potential of participatory approaches by drawing on Dörte's experience of participatory action research in the context of the participatory monitoring of municipal development plans in the Brazilian Amazon region. On the basis of this experience, we would like to advocate a differentiated perception of power relations in research, a decolonisation of participatory approaches and a systematic integration of PAR in development research as a way to engage with feminist postcolonial critique.

\subsection{Participatory processes as re-colonisation}

Participatory approaches reached a relatively prominent position in development practice and research starting in the 1970s (Chambers, 1983; Swantz, 1970). They seemed to be a solution for overcoming power asymmetries in development practice and research, presenting a potential answer to postcolonial concerns. However, power relations evolved and also persisted in these participatory processes (Cooke and Kothari, 2001; Guijt and Shah, 1998). 
While in some cases, participatory approaches might be empowering to the participants, they are nevertheless increasingly being used as a merely extractive instrument for data collection. Using them in an extractive way has rather disempowered than empowered people and created paternalism instead of ownership in many research and development projects (Dill, 2009). On many occasions, participatory approaches have resulted instead in processes of recolonisation: new hierarchies were created and it was mainly the development agencies, in the hope of realising the "perfect" development project, that benefitted from the time and resources invested by the communities - in terms of public image, but also in terms of money and power (Kapoor, 2005).

\subsection{Participatory action research - researching "without guarantees"}

Inspired by critical feminist research, Dörte wanted to go beyond merely extractivist participatory methods. Participatory action research (PAR) seemed to be a solution, since it encourages the co-production of knowledge by academic researcher and (non-academic) local groups in a collaborative (co-)research process (see Reason and Bradbury, 2001). PAR allows research to lead to action, and can itself even be seen as action. PAR seems to combine the goals of feminist and postcolonial concerns: to change power relations in the research process and to stimulate transformative action. It offers a radical challenge to the research process, especially its elements of how data is collected, what sorts of new knowledge result, what impacts these results have as well as who steers the process and benefits from the research (Kindon et al., 2007). While PAR appears to be an attractive way to respond to feminist (and) postcolonial claims of decolonising and breaking down hierarchies of knowledge production, it is difficult to translate into research practice, as the example of Dörte's research experiences in Brazil highlights. While attempting to follow the ethical concerns of PAR, she constantly questioned herself: who should have the very first research impulse? What if local partners are not willing (or are incapable) of formulating clear research priorities? What if it is (or seems to be) up to the researcher to translate problems defined by the local population into research priorities? Could such research still be considered a co-production of knowledge?

"Even if I wished for, planned and designed it differently, the steering of the [research] processes lay mostly in my own hands. At least it seemed to me that I was constantly giving impulses for planning, action or evaluation phases. Obviously, I integrated indirectly or only weakly enunciated ideas of the participating people and articulated or reformulated them. I assumed a central facilitation role in this action research, which made me reflect critically. Hence, I would rather call my procedure 'facilitated action research' " (Segebart, 2007:144145 , translated by the author).

Participatory methodologies including PAR are not free of power relations, but rather are constantly challenged by the problem of how to avoid or take into account power relations within the research process. Power relations prevail on various levels: within the group, institution or community; between group and researcher; and between men and women or different ethnic groups (Guijt and Shah, 1998). Often power relations emerge out of the geopolitical, institutional and financial setting in which the participatory project is embedded.

Dörte had to abandon her high expectations of "pure" action research and accept her role as a professional academic. A long process of reflection started about what Spivak (1990:9) called "unlearning one's privilege as loss". This activity was an inner process of recognising the history and circumstances of learned habits and prejudices, and unlearning dominant systems of knowledge and representation. She realised that having a person with a professional academic background in a group was simply a fact that did not need to be a source of constant paternalism and dominance within the group - at least if the person had done her/his "homework" (Spivak, 1990) and acknowledged that other group members had other capacities to contribute to the collaborative process (e.g. great familiarity with the subject, detailed technical and/or traditional knowledge, important social networks or political contacts, etc.). It can even be seen as beneficial or adding potential for the group in their common collaborative research process.

Nevertheless, the advantage of the academic researcher directing the research procedure might result in unequal power relations in the research process by assigning him/her the role of a group leader. This challenge might be met by at least two possibilities: one option would be that the researcher could act as a mentor and assist and build the capacities of the research group members in basic research methodology to help them steer the research process together with the researcher. This is highly time-consuming for all involved and has to be fully desired by the co-researchers. Another, less resourceintensive possibility is that the researcher can act as a facilitator (not leader) of the whole research process. $\mathrm{S} /$ he might take some decisions by her/himself (e.g. research impulse and applying for funding or documenting and disseminating research results) at some moments in the research process. The latter procedure is what Dörte has termed facilitated action research.

Facilitated action research also makes it possible for academics undertaking participatory research to bridge the "two conflicting social worlds" (Cancian, 1993) they constantly confront: on the one hand, academic scholars have to respond to academic standards to achieve career success (e.g. complying with strict time frames and publishing in academic journals). On the other hand, communities frequently 
question the relevance of academic research for meeting their needs and insist on other ways of representing research outcomes, such as videos, workshops and even transformations in daily life (Pain and Francis, 2003). PAR challenges current academic practices, like for example the authorship of research, the way research results are communicated, funding schemes and the length of time for research and qualification.

Given these criticisms and limitations, the question remains why a researcher would still consider participatory action research as an adequate feminist postcolonial research practice. Having experienced those research contexts as transformative spaces, as "contact zones" (Askins and Pain, 2011), we advocate a more rigid and systematic research on power relations in participatory research settings rather than abandoning participatory approaches altogether. Such research should provide a better theorising and systematising of participatory approaches (Kapoor, 2002) and engage with questions of how transformative social relations can be scaled up (Askins and Pain, 2011).

When implementing participatory approaches as a possible answer to feminist postcolonial criticism, Pain and Francis (2003:52) suggest "we should have no illusions that they present straightforward solutions to the ethical dilemmas surrounding research, to the imperative of making research have real impacts, or to the tensions between critical action and academic research." We should instead adopt "[a] rigorous reflexivity ... [which] requires a level of open-mindedness that accepts that participatory development may inevitably be tyrannical and a preparedness to abandon it if this is the case" (Cooke and Kothari, 2001:15).

\section{Taking into account intersectionality in development research and practice}

When Carolin studied in Quito in 2004 and worked for the German development cooperation (GIZ) with local governments, she became fascinated by the simultaneous empowerment processes of both the indigenous and women's movements. Talking with mestiza, indigenous and AfroEcuadorian women being elected into local governments, she developed an awareness of the way gender, ethnicity, and class intersected in the spaces of local governments and resulted in complex power relations (Schurr, 2009). Ecuador's contemporary process of political transformation, therefore, seemed an interesting case to empirically engage with the concept of intersectionality.

When she started her $\mathrm{PhD}$ research in 2008, intersectionality was the big "buzzword" (Davis, 2008) in the Germanspeaking feminist academic community. Emerging from Black Feminism (Crenshaw, 1989) and Third World Feminism (Mohanty, 1986), with some time lag, the concept travelled to Europe as a promising concept to come to terms with multiple oppressions (Knapp, 2005). Being committed to feminist postcolonialism, she considers the engagement with intersectionality as a possibility to respond to feminist postcolonial critique.

\subsection{Intersectionalising positionality}

"I was unable to discard or conceal the multiple aspects of my embodied identity that shaped my interactions in the field. Nor was I able to control the ways in which others positioned me" (Sundberg, 2005:19).

Feminist postcolonial criticism of how Western colonising has affected the production of knowledge (Parpart, 1993; Tuhiwai Smith, 1999) has provoked vibrant discussions in human geography for several decades. Debates unfolded about how our multiple yet intersecting identities influence the researcher's access to and experience in the field (Datta, 2008; Kobayashi, 1994), the collection and analysis of data (Sidaway, 1992), and the writing itself (Radcliffe, 1994). In fact, "it is now rare to find fieldwork-based feminist research that does not engage to some degree [...] with a reflexive analysis of how the production of ethnographic knowledge is shaped by the shifting contextual, and relational contours of the researcher's social identity" (Nagar, 2002:179). Emphasising how "different parts of [the] embodied social identity were given prominence in different situations" (Sundberg, 2005:19), these accounts seek to shed light on the way knowledge production is shaped by "positions of power due to their [the researcher's and the research partners'] position within specific gender, class, or racial hierarchies" (Mullings, 1999:339). Throughout the research project, Carolin had similar experiences to those described in these accounts regarding the shifting power relations that saturate our research process. Much has been written about the way our research is restricted by these power relations. Little, however, has been written on how our intersectional identities make it possible to establish "situated solidarities" (Nagar and Geiger, 2007:269) during our research process. Reflecting on the relationships with Carolin's research partners, she argues along with Mohanty $(2003 a, b)$ that feminist postcolonial research needs to shift its focus from the differences between "Western" and "Third World" women (Mohanty, 1986) to the possibilities and necessities of "cross-national feminist solidarity" (Mohanty, 2003b:509). The following field notes offer an opportunity to reflect on the way Carolin's own identity intersects with her interests and political positioning, as well as how rapport can be established through intersecting interests and concerns between the research partners and the researcher.

"I have already spent a few weeks in the Amazon town of Francisco de Orellana, when I attend, at the side of Balvina Pimbo the president of a local government, a workshop of female local politicians. The discussion turns around two 
issues: women's underrepresentation within rural local governments and the women's concern about dropping agricultural prices. Suddenly, Balvina Pimbo addresses me, asking what the situation is like for women in Switzerland. So far, I have told her little about my life in Switzerland, since our conversations focus on her everyday challenges as female president. So far my whiteness and academic background rather distance us. The women are clearly surprised when I tell about the recent struggle of Swiss women for suffrage that they gained on a national level only in 1971. Having imagined a highly industrialised, grand-scale agriculture (as in the US), they are even more surprised to hear about the struggles of Swiss farmers working in rural villages in the Alps.

Over time, the relationship with Balvina Pimbo has changed: our conversations turn more and more around the questions of how women can be mobilised to run as candidates in local politics, how farmers can cooperate or produce organic food in order to develop a sustainable agriculture in the region, and how the violence against women could be addressed in the remote indigenous communities - somehow my whiteness and the class difference between us seems less important every time" (field notes Schurr, February 2009).

The field notes show that, at the beginning, the relationships in the field were determined by common or different identity markers such as being a woman or having an academic background (Valentine, 2002). In the long run, however, shared interests, political aims or ideas of social justice became more decisive. The intersectionality of Carolin's own positionality and the ways her identity and political positions interconnected with those of her research partners enhanced and shaped her encounters in the field. In hindsight, when Carolin reflects on the key people in her three research sites, it is interesting to notice that different identities and interests facilitated the establishment of a rapport with each of these individuals. These relationships and the common political aims they were built on shaped the research process in particular ways in each of these three research contexts: they influenced the selection of people Carolin was introduced to and later interviewed, the activities she was actively involved in, her positioning in the field resulting from the way the key person would introduce Carolin and her research, or the topics discussed in interviews and everyday conversations. The concept of intersectionality has enriched Carolin's research process by urging her to focus on both the differences between her research partners and herself and the interconnectedness of their experiences, political aims and everyday struggles.

Leaving the individual level aside, and looking in a comparative manner at the situation of women in electoral poli- tics, the similar challenges women politicians face are striking - despite different historical contexts. By highlighting the commonalities rather than the differences in women's struggle for political rights across different national contexts, a transnational feminist solidarity can be built that confronts exclusions inherent in contemporary political systems and also advocates women's citizens rights on all political levels. The awareness of how our political visions intersect with the struggles of our research partners opens up the possibility to turn research into a collaborative decolonizing project built on "situated solidarity" (Nagar and Geiger, 2007:269).

\subsection{Intersectionalising development practice}

"An intersectional approach [...] addresses the manner in which racism, patriarchy, class oppression and other discriminatory systems create inequalities that structure the relative positions of women, races, ethnicities, class and the like" (United Nations, 2001).

This introductory quote shows that development agencies generally agree on the need for an intersectional analysis of power relations and the importance of recognising the multiple identities of target groups. While the commitment to an intersectional approach exists on a discursive level, development agencies struggle to integrate intersectional thinking into their everyday practices. Drawing on a collaborative research project between academic researchers, the German Development Cooperation (GIZ) and the Ecuadorian National Association of Local Governments (CONAJUPARE), we discuss the challenges of implementing intersectional thinking into development work.

GIZ approached Carolin with the following concern:

"The GIZ wants to develop a research project in response to CONAJUPARE demands in order to acquire more knowledge about the gender, ethnicity and age of the local politicians. The hypothesis of the CONAJUPARE is that women, indigenous and Afro-Ecuadorian, and young people would rather participate in local politics than in higher-level politics. CONAJUPARE is interested in identifying these leaders with the aim of providing them training based on their specific needs as well as a gender, intercultural and intergenerational focus" (internal minutes 19 August 2009).

A methodology was collaboratively elaborated. A quantitative survey was sent out to all local rural governments (JPR) with the aim to obtain detailed information about the gender, ethnicity, level of education, and age of all members of each of the 798 local governments in the country. On the basis of a purposively selected sample, 30 interviews were conducted with female, indigenous and young political leaders and then analysed with an intersectional approach (Winker 
and Degele, 2009). Thanks to the study, the CONAJUPARE obtained detailed information about the composition of the JPRs and the underrepresentation of certain groups. This information was employed to promote and support the integration of underrepresented groups in the electoral lists through workshops in the 2009 campaign.

At first glance, this project appears to be a best-practice example of how researchers and development and political agencies collaboratively integrate an intersectional perspective into their work. However, as we conducted and evaluated this project, we also became aware of the limits of and challenges to an intersectional approach in development practice.

On an empirical level, our research was constantly confronted with the question of which identity categories structure the access to and experiences in electoral politics. As with most intersectional studies, we focused on gender, ethnicity, class (level of education) and age. We struggled with the vagueness of the concept that does not define "which categories to use and when to stop" (Davis, 2008:77). In hindsight, after engaging with the reality of local politics in Ecuador through further research, Carolin thinks that there are other crucial categories that shape the access to and experience in local politics, such as local belonging, sexual orientation and marital status. It is certainly true that, "with each new intersection, new connections emerge and previously hidden exclusions come to light" (Davis, 2008:77).

On an operational level, an intersectional analysis aiming to contribute to more differentiated development practices and policies is confronted with the methodological challenge of first capturing and then disentangling complex power relations. This challenge is often accompanied by the high operational costs involved in running such complex studies.

On an institutional level, issues of intersectionality are often literally caught between two stools as gender issues are often covered by different institutions than (ethnic) minority issues (van der Hoogte and Kingma, 2004). Policies that promote one social group in an essentialist way, such as ethnic and gender quotas or training programmes exclusively developed for women or indigenous people, need to be rethought from an intersectional perspective to refine policies and projects.

\section{Conclusions}

We have outlined major challenges to doing fieldwork after the postcolonial turn, but despite these challenges, we would like to conclude by advocating the possibility and necessity of a feminist post postcolonial research agenda. Like any critical research, feminist post postcolonial research should constantly challenge its own assumptions, theories, methodologies and practices in order to address the limitations and problems previously discussed. We call for an engagement in critical globalisation research, which should be informed by interregional entanglements and a critical assessment of the researcher's own position and role in them. Reflections on research practices can and should result in new forms of partnership between researchers and those researched, and be steeped in mutual solidarity and collaborative political action. Here, we have aimed to show the mutual benefit of such a dialogue by discussing the impact of feminist postcolonial concerns on both development research and practice. On the one hand, feminist postcolonial approaches can inspire development cooperation in their attempt to decolonise development practices. On the other, changes in the design, realisation, and evaluation of development projects and everyday routines of development cooperation can reveal the benefits of feminist postcolonial approaches for social transformation. Hence, feminist postcolonial concerns should result in structural transformations of both knowledge production and development cooperation. These structural transformations include new funding schemes for research and development cooperation, a rethinking of evaluation criteria for both academic success and development progress, obligatory training in feminist postcolonial thought, and reflexivity in academia and development practice.

In this paper, we have discussed the limits and potential of participatory approaches and the concept of intersectionality for a feminist post postcolonial research and development agenda. To conclude, we would like to summarise to what extent both can be considered as "good" feminist (and) postcolonial approaches.

We have advocated participatory approaches for their (prospective) transformative potential. Whereas using participatory approaches in an extractive way can actually disempower those researched and even re-colonise research relationships, a power-sensitive and self-critical approach can actually de-colonise participation in research processes and in development practice. Participatory action research does address some of the shortcomings of conventional participatory approaches, but it is still not free from establishing a space inhabited by complex power relations. More modest facilitated participatory action research, which might include elements of mentoring, may effectively translate the idea of coproducing knowledge into practice. In development research, structural changes are needed in favour of participatory approaches, especially PAR, so that more sustainable conditions for these approaches to grow can be created and a feminist postcolonial research agenda can be implemented. Critical researchers (and development workers) should not stop using participatory approaches, but should do it in a modest and critical - in short, decolonising - way.

Turning now to intersectionality, the two very different reflections presented above on the use of this feminist postcolonial concept in development research and practice have highlighted the "open-endedness" of the concept (Davis, 2008:69). In the first section, intersectionality was employed as a tool to shed light on the way our own (political) positionality has interconnected with the intersectional positionality of our research partners - along common interests, political 
aims, and visions of social justice. We have argued that intersecting visual identity markers such as gender or ethnicity are not decisive for establishing rapport in the field but it is rather the way identities intersect with researchers' interests and political aims that is important. In contrast, the collaborative study presented in the second section is based on a more conventional understanding of the concept of intersectionality, looking at the intersections of gender, ethnicity, class and age regarding access to and experience in local electoral politics.

Along with Davis (2008), we would like to argue that it is the ambivalence and vagueness of the concept of intersectionality that makes it a productive tool to decolonise development research and practice in alignment with feminist postcolonialism. This vagueness opens up possibilities for a creative engagement with the concept in order to identify inclusions and exclusions along intersecting identity categories. Intersectionality has been confronted with a great deal of criticism but we think it provides an instance of "good" feminist theory in Butler and Scott's (1992:xiii) sense as "feminist theory needs to generate analyses, critiques, and political interventions, and open up a political imaginary for feminism".

\section{References}

Askins, K. and Pain, R.: Contact Zones: Participation, Materiality, and the Messiness of Interaction, Environ. Plann. D, 5, 803-821, 2011.

Butler, J. and Scott, J. (Eds.): Feminists Theorize the Political, Routledge, New York, 1992.

Cancian, F.: Conflicts between Activist Research and Academic Success: Participatory Research and Alternative Strategies, Am. Sociol., 1, 92-106, 1993.

Chambers, R.: Rural Development. Putting the Last First, Longman, Harlow, 1983.

Collins, P. H.: Black Feminist Thought: Knowledge, Consciousness and the Politics of Empowerment, Unwin Hyman, Boston, 1990.

Cooke, B. and Kothari, U. (Eds.): Participation. The New Tyranny?, Zed Books, London, New York, 2001.

Crenshaw, K.: Demarginalizing the Intersection of Race and Sex: A Black Feminist Critique of Antidiscrimination Doctrine, The University of Chicago Legal Forum, 1, 139-167, 1989.

Datta, A.: Spatialising Performance: Masculinities and Femininities in a "Fragmented" Field, Gender Place Cult., 2, 189-204, 2008.

Davis, K.: Intersectionality as Buzzword: A Sociology of Science Perspective on What Makes a Feminist Theory, Feminist Theory, 1, 67-85, 2008.

Dill, B.: The Paradoxes of Community-based Participation in Dar es Salaam, Dev. Change 40, 4, 717-743, 2009.

Guijt, I. and Shah, M. K. (Eds.): The Myth of Community. Gender Issues in Participatory Development, Practical Action, London, 1998.

Kapoor, I.: The Devil's in the Theory: A Critical Assessment of Robert Chambers' Work on Participatory Development, Third World Q., 23, 101-117, 2002.
Kapoor, I.: Participatory Development, Complicity and Desire, Third World Q., 26, 1203-1220, 2005.

Kindon, S., Pain, R., and Kesby, M. (Eds.): Participatory Action Research Approaches and Methods. Connecting people, participation and place, Routledge, New York, 2007.

Knapp, G.-A.: Intersectionality - Ein neues Paradigma feministischer Theorie? Zur transatlantischen Reise von "Race, Class, Gender", Fem. Stud., 1, 68-81, 2005.

Kobayashi, A.: Coloring the Field: Gender, "Race", and the Politics of Fieldwork, Prof. Geogr., 1, 73-90, 1994.

Koopman, S.: Alter-Geopolitics: Other Securities are Happening, Geoforum, 3, 274-284, 2011.

Laurie, N. and Calla, P.: Development, Postcolonialism and Feminist Political Geography, in: Mapping Women, Making Politics: Feminist Perspectives on Political Geography, edited by: Staeheli, L., Kofman, E., and Peake, L., London, 99-112, 2004.

Lewis, R. and Mills, S. (Eds.): Feminist Postcolonial Theory. A Reader, Routledge, New York, 2003.

Mohanty, C. T.: Under Western Eyes: Feminist Scholarship and Colonial Discourses, Boundary, 2, 333-358, 1986.

Mohanty, C. T.: Feminism without Borders. Decolonizing Theory, Practicing Solidarity, Duke University Press, Durham, 2003a.

Mohanty, C. T.: "Under Western Eyes" Revisited: Feminist Solidarity through Anticapitalist Struggles, Signs, 2, 499-535, $2003 \mathrm{~b}$.

Mullings, B.: Insider or Outsider, Both or Neither: Some Dilemmas of Interviewing in a Cross-Cultural Setting, Geoforum, 4, 337350, 1999.

Nagar, R.: Footloose Researchers, "Traveling" Theories, and the Politics of Transnational Feminist Praxis, Gender Place Cult., 2, 179-186, 2002.

Nagar, R. and Geiger, S.: Reflexivity and Positionality in Feminist Fieldwork Revisited, in: Politics and Practice in Economic Geography, edited by: Tickell, A., Sheppard, E., Peck, J., and Barnes, T., London, 267-278, 2007.

Pain, R. and Francis, P.: Reflections on Participatory Research, Area, 1, 46-54, 2003.

Parpart, J.: Who Is the "Other"?: A Postmodern Feminist Critique of Women and Development Theory and Practice, Dev. Change, 3, 439-446, 1993.

Power, M., Mohan, G., and Mercer, C.: Postcolonial Geographies of Development: Introduction, Singapore J. Trop. Geo., 3, 231-234, 2006.

Radcliffe, S.: (Representing) Post-Colonial Women: Authority, Difference and Feminism, Area, 1, 25-32, 1994.

Radcliffe, S.: Development and Geography: Towards a Postcolonial Development Geography?, Prog. Hum. Geog., 3, 291-298, 2005.

Radcliffe, S.: Development and Geography: Gendered Subjects in Development Processes and Interventions, Human Geography, 4, 524-532, 2006.

Raghuram, P. and Madge, C.: Towards a Method for Postcolonial Development Geography? Possibilities and Challenges, Singapore J. Trop. Geo., 3, 270-288, 2006.

Reason, P. and Bradbury, H. (Eds.): Handbook of Action Research. Participatory Inquiry and Practice, Sage, London, 2001.

Schurr, C.: Andean Rural Local Governments in-between Powerscapes, Mesa Redonda, Eichstätt, 2009.

Segebart, D.: Partizipatives Monitoring als Instrument zur Umsetzung von Good Local Governance - Eine Aktionsforschung im Östlichen Amazonien/Brasilien, Tübinger Geographische Stu- 
dien 147, Tübingen, 1-398, 2007.

Sharp, J.: Feminist and Postcolonial Engagements, in: A Companion to Political Geography, edited by: Agnew, J., Mitchell, K., and Toal, G., Oxford, 59-74, 2007.

Sharp, J.: Geographies of Postcolonialism, Sage, London, 2009.

Sidaway, J. D.: In Other Worlds: On the Politics of Research by "First World" Geographers in the "Third World", Area, 4, 403408, 1992.

Sidaway, J. D.: Spaces of Postdevelopment, Prog. Hum. Geog., 3, 345-361, 2007.

Spivak, G. C.: Can the Subaltern Speak, in: Marxism and the Interpretation of Culture, edited by: Nelson, C. and Grossberg, L., Urbana, IL, 271-313, 1988.

Spivak, G. C.: The Postcolonial Critic: Interviews, Strategies, Dialogues, Routledge, New York, 1990.

Sundberg, J.: Looking for the Critical Geographer, or why Bodies and Geographies Matter to the Emergence of Critical Geographies of Latin America, Geoforum, 1, 17-28, 2005.

Swantz, M. L.: Ritual and Symbol in Transitional Zaramo Society with Special Reference to Women, Gleerup, Lund, 1970.
Tuhiwai Smith, L.: Decolonizing Methodologies: Research and Indigenous Peoples, Zed Books Ltd., London, 1999.

United Nations: Background Briefing on Intersectionality, Working Group on Women and Human Rights, 45th Session of the UN CSW, http://www.rci.rutgers.edu/ cwgl/globalcenter/policy/ bkgdbrfintersec.html (last access: 24.10.2012), 2001.

Valentine, G.: People like Us: Negotiating Sameness and Difference in the Research Process, in: Feminist Geography in Practice: Research and Methods, edited by: Moss, P., Oxford, 116-126, 2002.

van der Hoogte, L. and Kingma, K.: Promoting Cultural Diversity and the Rights of Women: The Dilemmas of "Intersectionality" for Development Organisations, Gender and Development, 1, 47-55, 2004.

Wainright, J.: Decolonizing Development: Colonial Power and the Maya, Blackwell Publishing, Oxford, 2008.

Winker, G. and Degele, N.: Intersektionalität. Zur Analyse sozialer Ungleichheit, transcript, Bielefeld, 2009. 